\title{
How does monetary policy affect labor demand and labor productivity?
}

\section{Monetary policy easing initially supports labor demand, but persistent easing may slow down necessary restructuring and productivity growth}

Keywords: monetary policy, labor demand, productivity

\section{ELEVATOR PITCH}

By supporting aggregate demand, including by easing financial constraints that affect businesses and households, accommodative monetary policy increased employment during the 2008 financial crisis and its aftermath. But, monetary policies that ease financial pressures also reduce necessary restructuring that normally contributes to productivity growth. One reason why productivity growth has been weaker in the aftermath of the crisis is that aggressive monetary policy actions have weakened underlying supply-side performance and labor productivity.

\section{KEY FINDINGS}

\section{Pros}

๑ Policy loosening by central banks initially raises demand for labor by reducing the effect of financial constraints on employment through lower interest expenses.

- A severe fall in labor demand and reductions in employment can weaken an economy's supplyside performance through increased long-term unemployment and loss of potentially productive businesses; such effects reinforce the benefits of accommodative monetary policy during a downturn, at least initially.

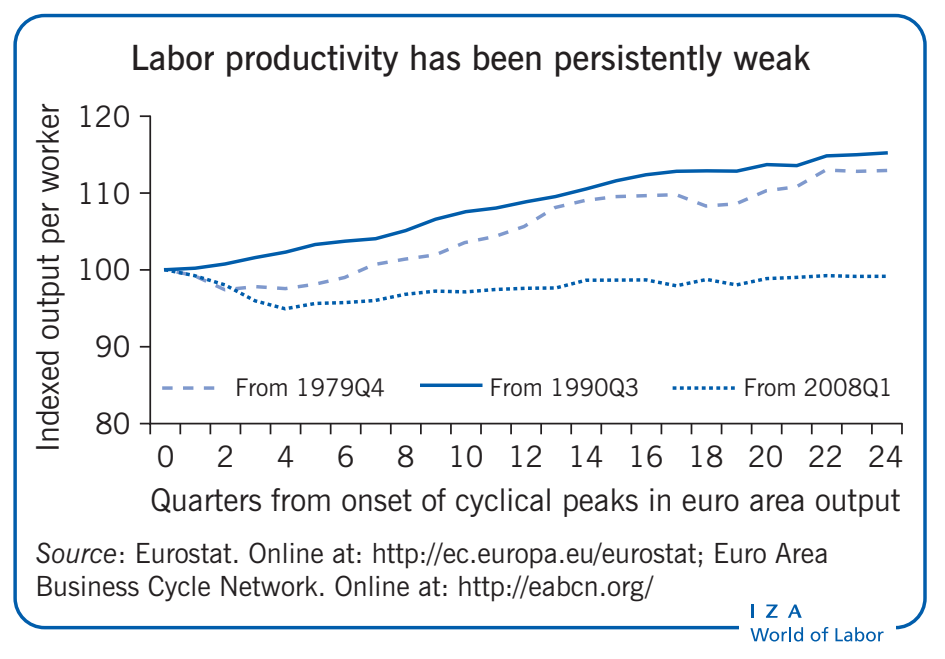

\section{Cons}

- Budget constraints necessitate the reallocation of resources to more productive uses; highly accommodative monetary policies that reduce financial pressures may mitigate this effect and thus weaken the underlying supply side of the economy.

- Monetary policy easing may reduce the positive effects of resource allocation to a greater degree in economies whose financial systems are bankbased as opposed to market-based.

\section{AUTHOR'S MAIN MESSAGE}

Monetary policy actions supported economic activity, labor demand, and employment during the 2008 global financial crisis, partly by avoiding the "hysteresis effects" (which raised the unemployment rate persistently) after past European recessions. However, if financial constraints continue to be reduced well into a recovery, this may impede productivity growth, job creation, and ultimately the strength of the recovery. While monetary policy loosening is an essential policy response to a downturn, timely removal of such policy, alongside other policies that raise productivity growth, is necessary for the medium-term strength of the recovery. 


\section{MOTIVATION}

A remarkable feature of the 2008 global financial crisis and its aftermath has been the scale of monetary policy response. Central banks in the US and Europe eased monetary policy through interest rate cuts to historic lows, large-scale asset purchase programs financed by the creation of central bank money (quantitative easing), and credit easing measures that subsidized credit expansion on favorable terms. Both the European Central Bank (ECB) and the Bank of England have recently turned to buying corporate bonds as a further means of policy action.

Monetary policy acts through a range of channels to affect nominal demand. One of these channels operates by affecting the incidence of liquidity constraints, which make business spending sensitive to current cash flows. Particularly at a time when credit supply is restricted, accommodative monetary policy (i.e. monetary loosening or easing) reduces the incidence of these financial constraints. In other words, it relieves financial pressures affecting businesses, primarily by reducing interest expenses and freeing up credit, and supports labor demand and employment.

Such actions may also have supply-side effects, including affecting available supplies of labor and capital, which operate through the incidence of financial constraints that makes business spending sensitive to current cash flows. In the short term, actions that support demand may avoid damaging supply-side effects via "hysteresis" or scarring effects, which means that subdued levels of output beget longer-lasting weakness [1]. Such hysteresis effects have been an important feature of Europe's past recessions, which are typically characterized by periods of high unemployment experience [2].

However, financial pressures are also part of the process that ensures that capital is reallocated from low to high productivity sectors and establishments. Such reallocation can be highly beneficial; it normally accounts for a significant fraction of labor productivity growth. While post-crisis unemployment rates have fallen-suggesting hysteresis effects have been avoided-labor productivity growth has remained persistently weak. The longer that exceptional policy easing from central banks persists, the greater the risk of adverse supply-side effects.

\section{DISCUSSION OF PROS AND CONS}

Modern macroeconomics has identified financial frictions as a key source of amplification of the business cycle. These frictions, which prevent an immediate clearing of a market, are likely to rise in a downturn, and especially in a financial crisis. For example, businesses may find it more difficult or costly to access finance even for a given risk-adjusted return on their investment. Applied microeconomics has concluded that financial constraints affect firms' labor demand by adding to effective borrowing costs. Evidence from firm-level studies shows how accommodative monetary policy supported labor demand and employment throughout the 2008 financial crisis and its immediate aftermath. Unemployment would have increased by more without such central bank actions to cut interest rates and adopt other "non-standard" ways of easing monetary policy, e.g. through quantitative easing programs and offering cheap term funding to banks.

\section{Impact of monetary easing on employment}

Figure 1 shows that, in Europe, the ratio of corporate interest payments relative to cash flow initially rose as the global financial crisis began in 2008, before falling markedly 
Figure 1. Interest expenses relative to cash flow

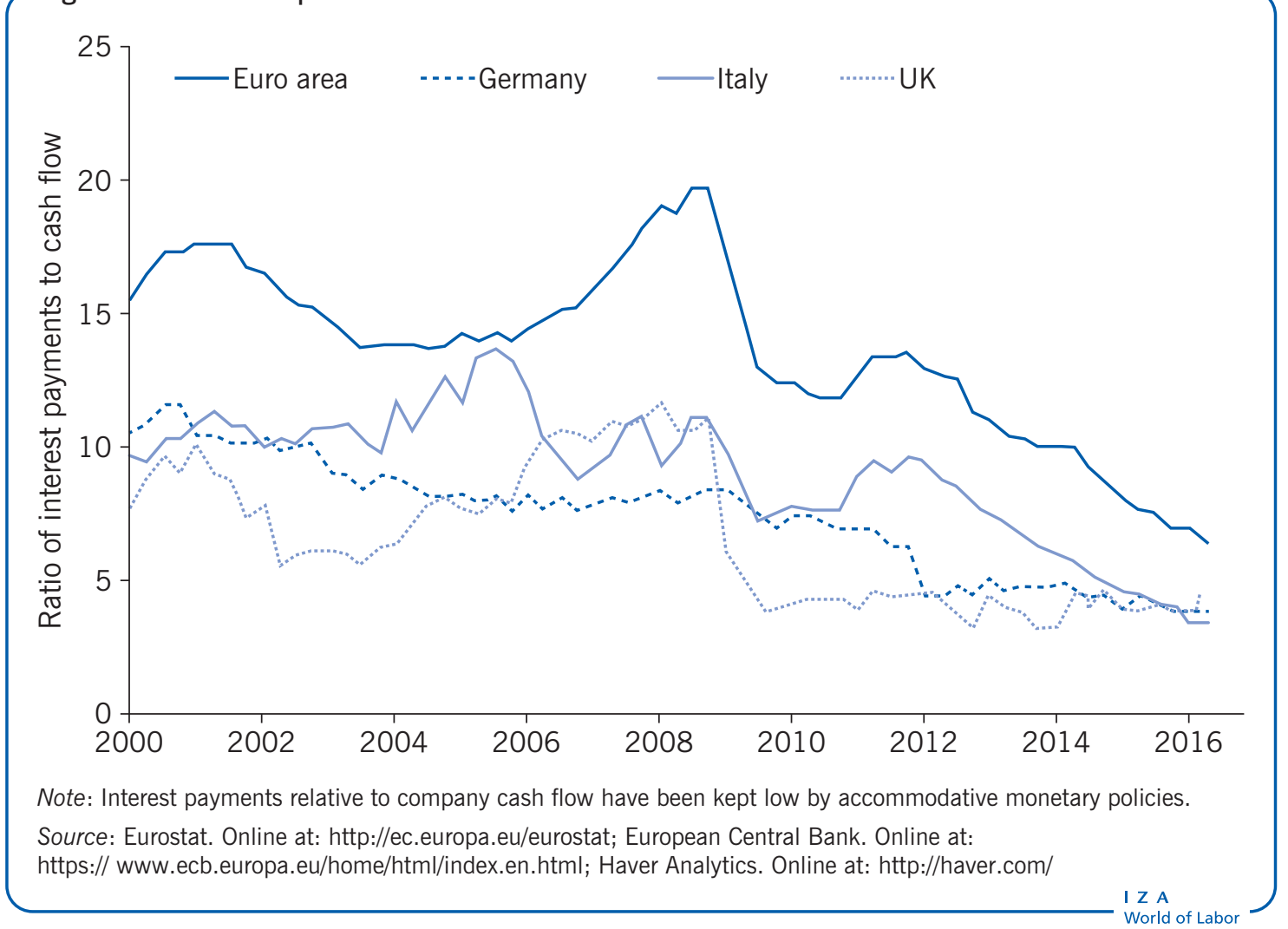

alongside actions by central banks to ease financial pressures by cutting interest rates as well as through other non-standard policy measures, e.g. buying government debt and giving cheap term funding to banks.

What kind of effect might such easing have on employment? In firm-level studies of labor demand, employment is shown to decrease as a result of financial pressure experienced by the firm-as measured by the ratio of interest payments to company cash flow. This ratio has been termed the "borrowing ratio" [3]. Loosening monetary policy, including cutting policy interest rates set by central banks, reduces interest payments and thus the financial pressure experienced by firms. The term captures the premium on borrowing costs and/ or the probability of credit being completely unavailable or rationed.

A sample of UK companies provides evidence of the expected link between monetary policy-via the borrowing ratio-and the level of employment [3]. Lower interest rates supported employment by reducing the cost of interest payments relative to cash flow. The effect was quantitatively quite large. A $10 \%$ reduction in interest expense increased companies' employment by around $0.5 \%$ in the short term (i.e. within the year) and by $2 \%$ in the long term (after five years or more).

Lower interest payments also lowered labor productivity or output per person employed at the firm level [3]. This effect was statistically significant but small in size. The study did not, however, assess the effect of a long period of low interest rates on labor productivity because there had not been such a period during the study.

In another analysis of manufacturing firms in 11 European economies for the period 20032011, a 10\% fall in interest payments (relative to cash flow) was found to raise employment 
by $0.35 \%$ in the short term; the study did not analyze long-term effects [4]. Moreover, the authors found that the positive effect on employment was greater during the euro area banking crisis period (from 2008) than in its non-crisis years, and the difference is found to be quantitatively large. In non-crisis years, the effect of a $10 \%$ rise in interest burden is less than $0.1 \%$; it increases to over $0.3 \%$ in crisis years.

Furthermore, the same study found that the effect of financial pressure was greater in peripheral euro area economies (such as Italy, Spain, Portugal, and Ireland) than it was in core euro area economies (including Germany) [4]. This may reflect the type of businesses in those peripheral economies, where there is a larger incidence of smaller, less-diversified businesses that are more bank-dependent for their financing. Overall, the pattern of results is consistent with a significant role for monetary policy in shaping labor demand through interest expense and the incidence of financial constraints.

Further supporting the above results, quite large effects were found from financial pressure on labor demand and employment in a large sample of manufacturing firms in Spain [5]. These effects also depended on some institutional elements of the labor market such as the incidence of permanent versus temporary contracts. Other company decisions-spanning both investment and corporate financing decisions (such as dividend payments)-have also been found to be sensitive to financial pressure [6], [7].

This evidence shows that a range of company decisions are affected by financial pressures. Some of these effects, such as businesses cutting dividends, are signs of business "coping strategies" as they try, imperfectly, to protect employment and investment decisions.

\section{From demand- to supply-side effects}

Reductions in financial pressure have also been shown to lower labor productivity [3]. The process of restructuring-via new entry and exit of businesses and establishmentsrepresents a quantitatively important part of normal productivity growth. Any factor that slows down the restructuring process through a slower pace of entry and exit may therefore adversely affect productivity growth.

In a large sample of UK establishments covering the period 1980-1992 it was found that around one-half of labor productivity growth resulted from "external restructuring" effects-the closure of inefficient plants and the entry and increased market share of more efficient establishments [9]. Anything that slows the external restructuring process down, making it more difficult for new businesses to enter a sector or weaker businesses to exit, would tend to retard productivity growth.

An important and perhaps surprising feature of the recent post-crisis experience is that business failures or company liquidations have been strikingly low. Figure 2 shows that business failures in several European economies have fallen in the aftermath of the crisis. In the UK and Germany, business failure levels have approached or reached historic lows. In Spain, they have fallen recently, after rising markedly during the European banking crisis (which intensified in 2012). Compositional factors such as the collapse of the housing and construction sector in connection with a large incidence of small businesses in Spain may account for some of these cross-country differences. 
Figure 2. Financial pressure has declined with falling interest costs

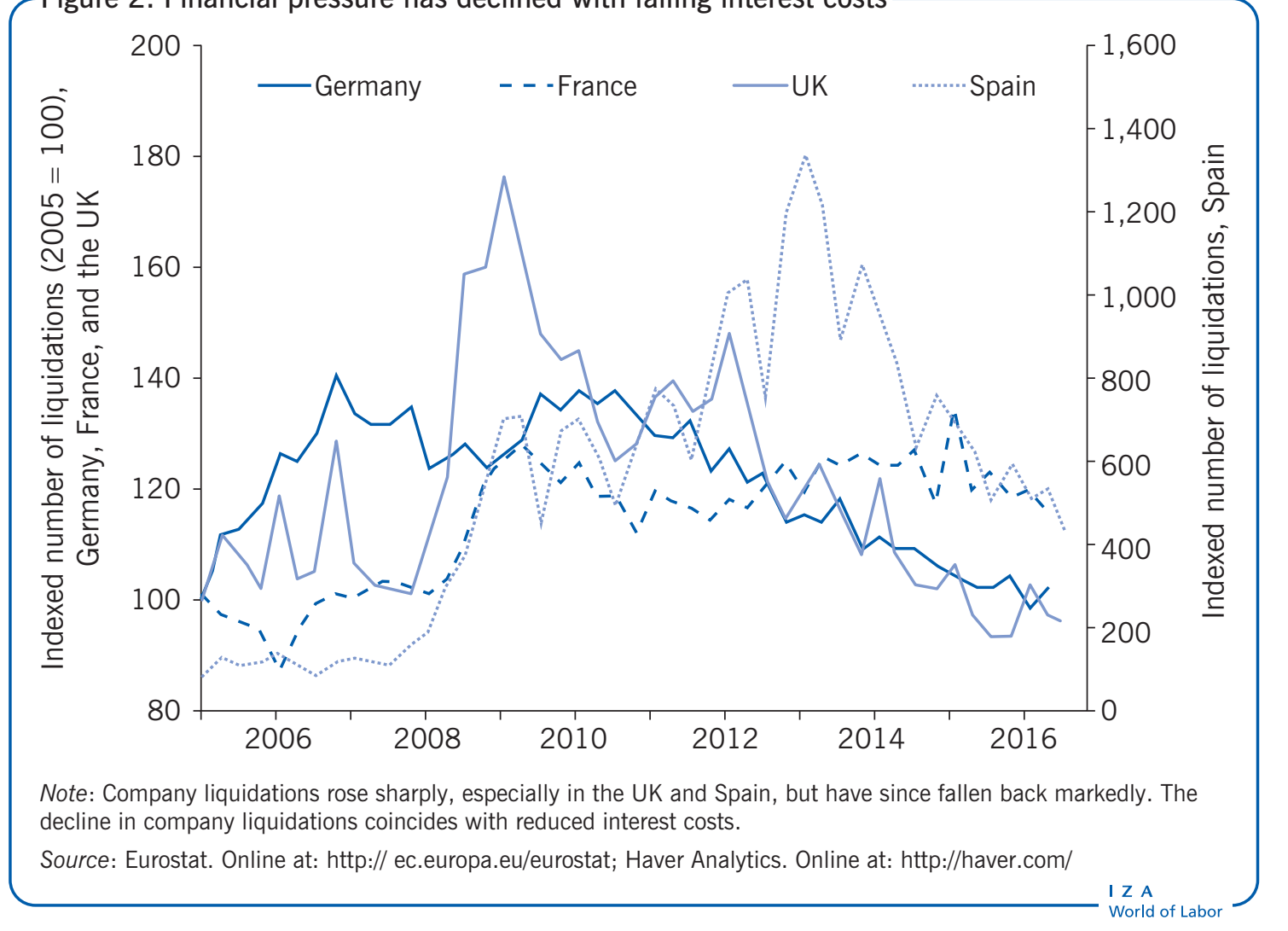

The decline in liquidations is less surprising given that interest expenses have fallen to historically low levels since 2008. Relevant studies have typically found that the borrowing ratio, which depends on interest expense, is an important determinant of business failures [10]. Considering this view, the finding that productivity growth at the firm level is raised within a year or two by financial pressure-and falls with an easing in the borrowing ratio-is more easily explained. Even in the short term, firms respond to rising financial pressure not only by scaling back employment, but also by reorganizing and closing down less efficient plants, which supports productivity growth.

In a sample of Italian firms, additional financial constraints were shown to cause firms to lower employment and raise productivity [10]. This finding is consistent with the view that a tightening of budget constraints raises productivity performance.

This view shares elements of the "zombification" story that is believed to have applied to Japan in the aftermath of the Bank of Japan providing liquidity to banks on a large scale [11]. Yet, rather than manifest through banks continuing to lend to low-productivity companies (as in Japan), in Europe, the effect has occurred because companies, including low-productivity ones are simply able to meet low interest expenses more easily. This would be bad news for the eventual strength of the recovery.

\section{Cleansing versus scarring effects of recessions}

Possible supply-side effects (on available labor, capital, and productivity) relate to the potential existence of "cleansing" versus "scarring" effects of recessions. Cleansing effects support productivity whereas scarring effects weaken it. 
In one model, both cleansing and scarring effects exist and shape productivity growth via resource reallocation effects, including through business entry and exit [12]. The cleansing effect results from low productivity companies exiting during a recession. The scarring effect is due to the tendency for predominantly young businesses, which might later develop into high growth businesses, being especially prone to exit in a downturn.

In calibrating the model to match historic data on business entry and exit, the scarring effect of a recession dominates and average productivity falls during a recession. However, it is not clear that this result applied in the Great Recession, which followed the near-collapse of Lehman Brothers in 2008, because (i) the corporate failure rate has been unusually low, affecting both cleansing and scarring effects, and (ii) the substantial monetary policy loosening has lowered expenses for highly indebted businesses, which tend to be more mature than young businesses who typically drive the scarring effect and whose sources of finance are largely internal funds.

If correct, this would mean a different explanation is needed for why labor productivity was so weak after the Great Recession. One potential explanation could be the activism of central banks in maintaining a persistently loose policy stance.

There is not yet much empirical evidence on the cleansing and scarring effects of the Great Recession. In the US, recessions before 2007 were characterized by periods of accelerated reallocation, which were even more productivity enhancing than out-of-recession periods [13]. In the Great Recession, by contrast, the intensity of reallocation fell rather than rose and the reallocation that did occur was less productivity enhancing than in prior recessions [13].

Overall, recessions can have a cleansing effect as well as a scarring effect; however, which effect dominates depends crucially on the recession's features. Those key features are likely to include the scale and persistence of the policy response to a given recession and the type of businesses that benefit as a result of that response.

\section{From restructuring to productivity performance}

Labor productivity performance has been disappointing across Europe since the Great Recession (see Figure 3), although some economies have seen slightly better productivity performance, such as Spain and Ireland. These countries have generally had some form of economic restructuring imposed on them for reasons unrelated to monetary policy. In Spain and Ireland, this resulted from the unavoidable collapse of low productivity housing and construction sectors. The collapse of those low productivity sectors naturally released resources and implied some form of unavoidable restructuring.

What does the evidence reviewed mean for the interpretation of employment and productivity in Europe? Overall, it suggests a pattern in which the ECB and the Bank of England supported higher levels of employment by alleviating financial pressures on businesses-by cutting interest rates and implementing other non-standard policy measures (e.g. quantitative easing programs), and by offering cheap term funding to banks.

Yet, persistent central bank action designed to alleviate financial pressures well into a recovery may also stunt labor productivity growth via reduced reallocation and, as a result, real wage growth. 
Figure 3. Stagnant UK labor productivity

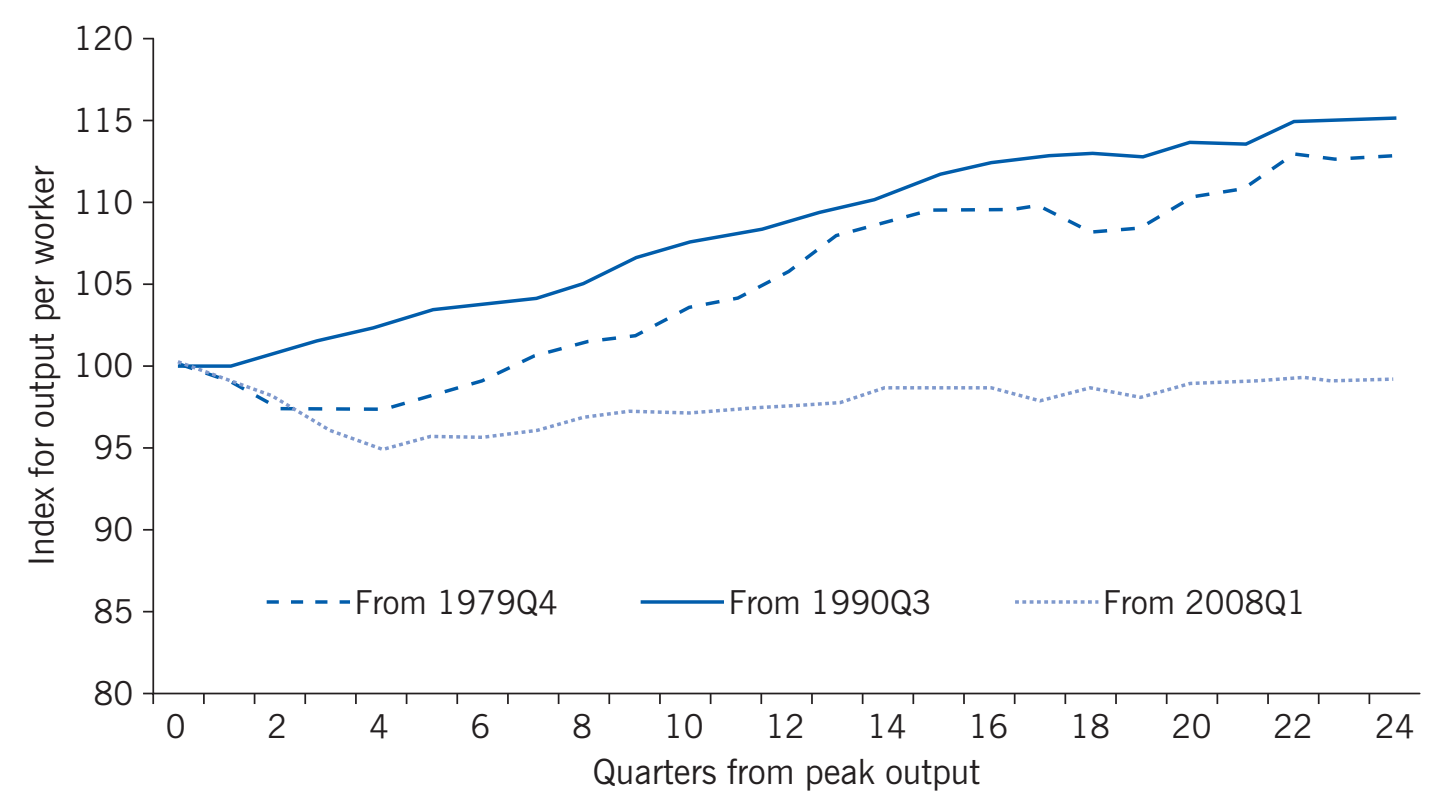

Note: UK labor productivity has been unusually weak following a period of low company liquidations and low interest rates.

Source: Office for National Statistics. Online at: https://www.ons.gov.uk

The form of central bank easing may also matter in terms of its supply-side effects. Actions by central banks to ease financial pressures during and after the 2008 crisis in an attempt to stabilize activity and inflation have gone beyond conventional interest rate cuts to include unconventional monetary policy. For example, quantitative easing programs, such as asset purchase programs, involved the outright purchase of assets, notably public debt and corporate bonds. Additionally, credit easing measures made term funding available to banks on favorable terms, in some cases incentivizing lending to the real economy (e.g. the Bank of England's Funding for Lending Scheme and Term Funding Scheme and the ECB's Targeted Long-term Repo Operations). Through these channels, the more bankbased an economy's financial system is, the more severe these adverse side-effects might be.

Asset purchase programs aim to reduce term premiums (affecting longer-term market interest rates) in the first instance and encourage a search for greater yield as a result. They do this partly through a process called "portfolio rebalancing," in which those who sell their safe assets to the central bank rebalance their portfolios toward riskier assets in a search for higher yield.

However, reduced term premiums also reduce banks' interest margins and the rewards they get from borrowing short-term to lend long-term. If banks face a reduced reward to lend, and indeed, if they receive a subsidy for maintaining existing lending rather than seeking out new, perhaps riskier borrowers, then this weakens their incentive to discriminate among borrowers and to play their normal role in reallocating resources from low to high productivity establishments and firms. More generally, economic restructuring is weakened when businesses are able to pay near-zero interest rates. The weak productivity performance in the post-crisis period is consistent with this perspective. 


\section{LIMITATIONS AND GAPS}

It is important to remember that the evidence presented here does not emerge in a laboratory-style experiment. The circumstances in which central banks have been called upon to act in unprecedented ways have been unique. Micro-level data, which controls for unobserved characteristics, may go some way to help control for some of these unique features. But, identifying the counter-factual of what would have happened to employment and labor productivity had central banks not acted in the way they did is a highly uncertain exercise.

Moreover, other factors may have influenced the measures evaluated in this article, some of which may have preceded the crisis. For instance, it is likely that a range of structural and technological factors are likely to have influenced the weakness in labor productivity. These would need to be incorporated into a fuller assessment of the economic effects of the policy response to the crisis in order to more completely understand the mechanisms at play.

\section{SUMMARY AND POLICY ADVICE}

Monetary policy has a difficult balance to strike between supporting the demand-side effects of alleviating financial pressures while minimizing the adverse effects of such actions on the economy's supply side. Monetary authorities are right to act aggressively to lower interest expenses for businesses in an economic and banking crisis. They are also right to avoid high levels of financial pressure, which would inevitably weaken the inflation outlook as well as employment. By doing so, they would also reduce the risk of so-called hysteresis or scarring effects of unemployment, which have operated in Europe in the past.

However, the longer that highly accommodative monetary policy persists, the more this may tip the balance toward adverse supply-side effects, especially via persistently weaker labor productivity. That might especially apply once unemployment rates have been lowered to pre-crisis levels. Striking this balance is likely to dominate discussions of setting the right monetary policy in Europe for years to come.

\section{Acknowledgments}

The author thanks two anonymous referees and the IZA World of Labor editors for helpful suggestions on earlier drafts. All views expressed are personal. Previous work of the author [5], [6], [7] contains a larger number of background references for the material presented here and has been used intensively in all major parts of this article.

\section{Competing interests}

The IZA World of Labor project is committed to the IZA Guiding Principles of Research Integrity. The author declares to have observed these principles.

(c) Andrew Benito 


\section{REFERENCES}

\section{Further reading}

Draghi, M. "The ECB's recent monetary policy measures: Effectiveness and challenges." Camdessus Lecture, International Monetary Fund, Washington, DC, May 14, 2015.

Santor, E., and L. Suchanek. "A new era of central banking: Unconventional monetary policies." Bank of Canada Review Spring (2016): 29-42.

\section{Key references}

[1] Gali, J. Hysteresis and the European Unemployment Problem Revisited. Paper Presented at the ECB Forum on Central Banking, 2015.

[2] Ball, L. Hysteresis in Unemployment: Old and New Evidence. NBER Working Paper No. 14818, 2009.

[3] Nickell, S., and D. Nicolitsas. "How does financial pressure affect firms?" European Economic Review 43:8 (1999): 1435-1456.

[4] Fernandes, F., A. Kontonikas, and S. Tsoukas. On the Real Effects of Financial Pressure: Evidence from Euro Area Firm-level Employment During the Recent Financial Crisis. SIRE Discussion Paper No. 2014028, 2014.

[5] Benito, A., and I. Hernando. "Labour demand, flexible contracts and financial factors: Firmlevel evidence from Spain." Oxford Bulletin of Economics and Statistics 70:3 (2008): 283-301.

[6] Benito, A. "Financial pressure, monetary policy effects and inventories: Firm-level evidence from a market-based and a bank-based financial system." Economica 72:286 (2005): 201-224.

[7] Benito, A., and G. Young. "Financial pressure and balance sheet adjustment by firms." Oxford Bulletin of Economics and Statistics 69:5 (2007): 581-602.

[8] Disney, R., J. Haskel, and Y. Heden. "Restructuring and productivity in UK manufacturing." Economic Journal 113:489 (2003): 666-694.

[9] Geroski, P., and P. Gregg. Coping with Recession: UK Company Performance in Adversity. Cambridge, UK: Cambridge University Press, 1997.

[10] Bertero, E., and L. Rondi. "Financial pressure and the behaviour of public enterprises under soft and hard budget constraints: Evidence from Italian panel data." Journal of Public Economics 75:1 (2000): 73-98.

[11] Caballero, R. J., T. Hoshi, and A. K. Kashyap. "Zombie lending and depressed restructuring in Japan." American Economic Review 98:5 (2008): 1943-1977.

[12] Ouyang, M. "The scarring effect of recessions." Journal of Monetary Economics 56:2 (2009): 184-199.

[13] Foster, L., C. Grim, and J. Haltiwanger. Reallocation in the Great Recession: Cleansing or Not?. NBER Working Paper No. 20427, 2014.

\section{Online extras}

The full reference list for this article is available from:

http://wol.iza.org/articles/how-does-monetary-policy-affect-labor-demand-and-laborproductivity

View the evidence map for this article:

http://wol.iza.org/articles/how-does-monetary-policy-affect-labor-demand-and-labor-

productivity/map 